Pittsburgh University School of Law

Scholarship@PITT LAW

\title{
Between Realism and Resistance: Shi'l Islam and the Contemporary Liberal State
}

Haider Ala Hamoudi

University of PIttsburgh School of Law, hamoudi@pitt.edu

Follow this and additional works at: https://scholarship.law.pitt.edu/fac_articles

Part of the Arabic Studies Commons, Comparative and Foreign Law Commons, Islamic Studies Commons, and the Islamic World and Near East History Commons

\section{Recommended Citation}

Haider A. Hamoudi, Between Realism and Resistance: Shi'l Islam and the Contemporary Liberal State, 11 Journal of Islamic Law and Culture 107 (2009).

Available at: https://scholarship.law.pitt.edu/fac_articles/109

This Article is brought to you for free and open access by the Faculty Publications at Scholarship@PITT LAW. It has been accepted for inclusion in Articles by an authorized administrator of Scholarship@PITT LAW. For more information, please contact leers@pitt.edu, shephard@pitt.edu. 


\title{
Between realism and resistance: Shi' $i$ Islam and the contemporary liberal state ${ }^{1}$
}

\author{
Haider Ala Hamoudi \\ University of Pittsburgh School of Law
}

\begin{abstract}
On the question of commitment to the nonliberal state, Shi $i$ doctrine, which can best be gleaned from the voluminous works of modern Grand Ayatollahs, can be ambiguous. Nevertheless, some forms of what might be dubbed orthodox Shi' ism appear more compatible with modern notions of liberalism than others. This Article divides modern Shi $i$ thought on the nation-state, and the devout believers relationship thereto, into four categories. The Article concludes as a general matter that at least three of those categories appear possibly compatible with liberalism, and a fourth almost appears to recommend liberalism as a preferred form of political order. Nevertheless, the association of liberalism with Western thought at a time when so much of the global Muslim community is deeply hostile to the West and its ideas creates a substantial obstacle to its broader adoption.
\end{abstract}

Keywords: liberalism; Islam; shi'ism; Sistani; Fadlallah

Earlier this year, when I was asked to deliver a paper on Shi' ism and the non-Muslim liberal state, I had a moment's hesitation. Despite my considerable interest in the subject, I did wonder as to my qualifications to address the question. I am neither a political scientist, nor a political philosopher, but rather a lawyer whose particular area of focus concerns Islam and commercial, not political, order. Nevertheless, finding so much that is profoundly dissatisfying in contemporary discussions on Islam, and in particular Shi'i Islam, in law and politics, and believing that my own, limited area of expertise might help to shed some light on a question of this importance, I agreed, and hope that my thoughts will prove to be at least edifying enough to justify the amount of time necessary to consider them.

I should note at the outset that as I am not a political philosopher, it is not my purpose to explore in any depth or detail any particular theory of liberalism or approach thereto, but rather to look to what I know best - the relationship under Shi' $\mathrm{i}$ doctrine between religious rules and state law. From this, much can be gleaned about how a Shi' $i$ is expected to conduct his affairs in a non-Muslim liberal state, but as to whether or not this would make a Shi' $i$ an exemplary, acceptable or bad citizen of that state, I will leave to those more trained in political philosophy than I to answer.

In spite of that qualification, I can state with a reasonably high degree of confidence my conclusion that while Shi' $i$ doctrine does not require participation in a liberal state, nor does it advocate generally for broad social cooperation in a manner

Email: hamoudi(a, pitt.edu

'Special thanks to my research assistant Robin Belinsky for her extensive research into the writings of Grand Ayatollahs Sistani and Fadlallah.

ISSN 1528-817X print/ISSN 1753-4534 online

c 2009 Taylor \& Francis

DOI $10.108(15288170903273029$

http:/www.informaworld.com 
that transcends the Shi' $i$ paradigm, still, depending on the particular approach to Shi'ism, being both a devout Shi'i and a devoted citizen of a liberal non-Muslim state seems eminently possible, with one significant obstacle which I will address at the end.

First, a rather lengthy note on methodology, for it is here where I probably depart most dramatically from my colleagues. I see no point and no purpose to the proclivity in American law schools to dwell excessively, or indeed at all, on the jurists of the classical age to address questions relating to the compatibility of Shi' $i$ doctrine, or Islamic doctrine generally, with a liberal theory of statehood. After all, the question we are addressing is whether or not contemporar Muslims, with their contemporary understandings of Islamic text, can be made to reconcile themselves with modern liberalism in a non-Muslim liberal state.

If I might illustrate the point through a personal anecdote, to which I will revert later in my paper, many years ago, when I was much younger, and in the course of performing the Muslim rite of pilgrimage to Mecca, my father and I traveled to Medina to see the Prophet's tomb. The experience was entirely moving for both of us, for obvious enough reasons, and my father began a common Shi' $i$ invocation at the tomb, at which time one of the nearly uniformly brutal Saudi guards struck him, shoved him to the floor, spat on the ground near him and said, "Ibn Taymiyya says that you [meaning, I presume, Shi'i s] are all dirty infidels." It was some number of years before I even read a word of Ibn Taymiyya, and I cannot deny even now approaching the text with some level of hostility. Shi' is throughout the Muslim world feel similarly about the figure of Ibn Taymiyya, again from the popular Wahhabi projection of him as justifying the declaring of Shi"is, commonly referred to as "rejecters" (rawäfid) within the Wahhabi paradigm, as infidels. ${ }^{2}$

As a result, while I am of course deeply appreciative of the justly celebrated work of Dr Sherman Jackson respecting the historical figure of Ibn Taymiyya, how deeply he has been misunderstood, and how his views cannot be the basis for the modern Wahhabi movement, ${ }^{3}$ I am also certain that none of this will stay the hand of the next Saudi guard. This is not to disparage Dr Jackson's magnificent efforts, only to point out their limitations when taken in directions he may not have intended, to reflect on the actions of substantial numbers of extremist Muslims at least purporting to apply his ideas.

Of course, this notion of the reinvention of history to authenticate contemporary social, political and religious movements is not limited to my own personal biography, or to Sunni fanatics. Islamic finance (of both the Sunni and Shi'i variety) is in fact a wonderful example of this phenomenon, weaving together opinions of various jurists in a manner that prohibits money interest, but not so extensively as to make elaborate artifices that achieve the same economic result impossible. ${ }^{4}$ Different combinations of

\footnotetext{
${ }^{2}$ Perhaps no better reference for this phenomenon of equating Ibn Taymiyya with puritanical Wahhabism exists than the fact that a very popular website extremely supportive of the Saudi clerics lies under the domain name "taymiah.net" and combines strident anti-Shi 'ism with a biography of the life and times of Ibn Taymiyya. See <www.taymiah.net>

${ }^{3}$ Cf. Sherman A. Jackson, 'Shari'ah, Democracy and the Modern Nation-State' (2003) 27 Ford Intl L J 88, 106. Jackson's extensive knowledge of Ibn Taymiyya also appears in his highly regarded work, Islamic Law and the State: The ('onstitutional Jurisprudence of Shihäb al-Dìn al-Qarā $\bar{f} \bar{l}$ (Brill, Leiden 1996) 5, 20, 70, 205-7.

${ }^{4}$ Haider Ala Hamoudi, 'The Muezzin's Call and the Tolling of the Dow-Jones Bell: On the Necessity of Realism in the Study of Islamic Law' (2008) 56 Am J Comp L, 423, 460-464.
} 
jurists could be used to permit money interest entirely, or to impose a meaningful prohibition, but this is not the point. Islamic finance seeks to resist the Western paradigm in form and rhetoric while accepting it, for lack of any alternative, in substance, and the classical doctors' exegeses are taken together to provide this necessary outcome.

At other times, when the jurists cannot be made to advocate a position that the modern Muslim world would like to claim as its own, they are ignored virtually entirely. For example, it would be well nigh impossible for me to explain the basis upon which Islam could be reconciled with a prohibition of slavery, if my only tools were the jurists, be they Sunni or Shi' $i$, of the classical era. The institution was firmly established. The rules are set forth clearly in the classical manuals and while there was dispute between jurists about the precise contours of the rules, there is no question that practices that the modern world considers abhorrent were openly tolerated.

Why then are there few conferences on the compatibility of Islam with emanicipation? The reason, it seems, is obvious: modern Muslims do not care about the classical rules. As my colleague Bernard Freamon has pointed out, there is a contemporary consensus in favor of a ban on slavery. ${ }^{5}$ Thus are the classical jurists are ignored, and a return is made to the foundational sources, to God's Word, the Holy Qur'an, and the statements and utterances and actions of Muhammad, the Sunna, to make a plausible case for emancipation, on the theory that slavery was always meant to be discouraged and the seeds for its destruction were laid in the restrictions placed upon the practice. ${ }^{6}$

This notion of ignoring the classical when inconvenient in favor of an entirely new approach based on foundational text extends well beyond the topic of slavery; the entire area known as stipulation in contract has been all but entirely discarded. ${ }^{7}$ The point is that when modern political and social circumstances do not make the positions of the classical jurists useful, as in slavery, a story is woven that ignores the classicists and suggests that Islam lay the seeds for the prohibition of slavery in its historical texts, even if it could not ban the abhorrent practice immediately outright due to broader social and economic circumstances - a wonderful story, an inspiring one and yet deeply ahistorical, conveniently ignoring nearly a millennium of Islamic legal thought on the question. But it is the story to which the vast majority of modern Muslims adhere.

Feminist Muslims try the same with respect to the institution of polygamy, coming up with a story strikingly parallel in composition to that which animated the slavery prohibition; namely, that Islam's earliest texts discourage and sharply delimit the practice of polygamy in a manner that is consciously intended to lead to its destruction, irrespective of what the classical jurists may have said. ${ }^{8}$ Yet feminism, I probably

\footnotetext{
${ }^{5}$ Bernard Freamon, 'Slavery, Freedom and the Doctrine of Consensus in Islamic Jurisprudence' (1998) 11 Harv Hum Rts $J$ 1, 7 ("...despite the sordid history of slavery in the Arab world, there now appears to be a broad consensus among lay Muslims and expert Muslim jurists that slavery is... legally forbidden and that no true Islamic state can allow it to exist.")

${ }^{6}$ Ibid. 34-53 (providing the basis for such a claim).

${ }^{7}$ Hamoudi (n 4), 445-448.

${ }^{8} \mathrm{~A}$ good example of such a Muslim feminist would be Professor Asma Barlas of Ithaca College, who has taken precisely such a position in much of her work. Cf, Asma Barlas, Women in Islam: Facts and Perceptions, delivered to the Conference on Muslim Women's Health Needs at the University of Illinois (Chicago), 4 March 2005.
} 
need not say, is for the most part a very marginal influence on Muslim thought, and women"s rights tend to correlate inversely with the degree of Islamization in any society. Individuals promoting such ideas have a greater following among Western academics and liberal Muslim elites than they do among the deeply devout. The masses of Islam's adherents dismiss such notions as some sort of Western apologia.

Given how the community has evolved its norms and rules over the past few centuries to meet contemporary needs and expectations, I am surprised by the unnatural and distracting affinity of academics in law schools and political science departments, with the classical exegeses, rather than the modern circumstances that give rise to modern Muslim opinion. It is not as if the modern world wants for sources of modern Muslim law. What of the writings, I wonder, of the immensely popular Yusuf al-Qaradawi, Khaled Amr and Ali Sistani? What of the blogs with questions and answers from faithful to scholar, and the comments thereon? What of the websites of large Muslim organizations, what of the conferences held on Shari'a in the modern age, what of the many courts throughout the world purporting to examine Islamic law, in multiple areas? Are these to count for nothing? Must we be stuck forever in antecedents?

I submit that this unnatural focus on the classical world has led to a fundamental lack of understanding of what Islamic law is in our times. There are certainly moments when I have heard things I would describe as horrifying in the academy to explain modern divergence in many cases from classical theory - that Islamic legal theory has ceased to exist, that modern Muslims' call for Shari'a betrays a fundamental ignorance about what they want, that the popular preachers and scholars and polemicists who have swept the Islamic world (not to mention judges applying the Shari'a in various Muslim countries) are "unorthodox" in their approach, that modern legal approaches to the Shari'a (among them codification) are, to use Schacht's phrase, "distorting", 9 as if it is we outsiders (whether Muslim or not) in the American legal academy, rather than those assigned with the task of decision making, who determine what is and is not orthodox, what type of evolution is manipulative and distorting and what is not. An alternative approach assumes that when laypeople, legislators, judges and religious scholars call for Shari'a they are not silly ignoramuses but in fact have very real ideas of what they want and expect, ideas that conform to their own biases, assumptions and ideological predispositions, and that the outcomes ultimately selected by this body politic are many more times "Islamic", in the context of our times, than anything any jurist might have said several centuries ago. Such an approach, I submit, would lead to considerably more clarity. In some cases the results might be disturbing, in others encouraging, but at all times, far more accurate and enlightening than much of the history obsessed scholarship I have read coming out of law schools, schools of government and political science departments.

I suppose this lengthy introduction is to do no more nor less than justify my approach to this subject, which is to pay no attention to historical antecedents and focus instead on what it is that Muslims, and in my case specifically Shi'i Muslims, look to when examining the question of liberalism and its compatibility with Shi' $i$ Islam in the specific context of Western non-Muslim societies. The question is in some important respects much easier to answer than any comparable question in the Sunni context, given the structural nature of Shi'i Islam. Determinations of legal

9Joseph Schacht, 'Problems of Modern Islamic Legislation' (1960) 12 Stud Isl 12. 
rules in Shi'i Islam are made individually by high scholars known as mujtahids, generally graduating (after decades of study) from the seminaries of Najaf and Qom in Iraq and Iran, respectively. Each Shi' $i$ lay person is required to select one living mujtahid (often also referred to as Grand Ayatollahs) to be his source of imitation (marja' al-taqlid) and to follow the rulings of that mujtahid absolutely, unless ill defined "legitimate circumstances" require a change. ${ }^{10}$ The sources of the rules of Shi' $i$ Islam are, as a result, relatively finite. Naturally this is not to suggest that all Shi'i Muslims are so uniformly devout as to follow all of these rules, but to the extent that we are talking of the compatibility of Shi' $i$ Islam with modern liberalism, we must proceed under these established premises of modern Shi'i Islam. What the modern jurists say will in the end control the positions of many of the devout.

The task, however, of identifying core Shi' $i$ belief on liberal theory from the writings of the mujtahids is not as simple as it may seem. First of all, while looking to the distant, classical past may not be fruitful, it does seem rather unusual, in trying to gather a sense of modern Shi ism on this vital question, to exclude particularly influential mujtahids who died within the past half century. While it is true that adherents cannot select a deceased mujtahid as a source of imitation, there can be no doubt that such giants of the seminaries as Muhsin al-Hakim, Muhammad Baqir al-Sadr, Ruhollah Khomeini and Abul Qasim al-Khoei have had an immense, and immediate, effect on the mujtahids of today, many of whom were once their pupils. Taking the dozens of more prominent mujathids of the past half century together, reading through their multi-volume compendia of legal rules, each referred to as a risäla amaliyya, as well as any other rulings or decrees they may have made, and trying to draw generalizations on theories of liberalism and the obligations of Shi' is in a non-Muslim liberal state, an entity with which these eminent individuals would be most unfamiliar, would be a daunting task that I cannot claim to have undertaken entirely.

Adding to the difficulty, as I will demonstrate later in my remarks, is the fact that the mujtahids often seem to take positions of strategic ambiguity, which is particularly maddening for a lawyer, trained to value clarity and straightforwardness in analysis. As to why the mujtahids do this, one can only speculate, but it seems to arise partly out of a desire to mediate differences among the clergy, partly to ease tensions when taking controversial positions (among which certainly liberalism would be one) and partly to allow for future flexibility. This makes their views particularly ripe for a wide range of potential interpretations by later disciples.

All of these considerations notwithstanding, in the course of my own scholarship, I have had occasion to read reasonably carefully significant portions of the compendia and rulings of the more well known scholars, as well as to gain some familiarity with their personal histories, and certainly have at least glanced at the works of many more, from which I might humbly offer to categorize modern Shi' $i$ thought on the relationship of religion to state into four distinct categories, modifying the conventional wisdom, which mentions only two. These categories I describe as Islamism, Semi-Quietism, Quietism and Ambiguous Liberalism.

\footnotetext{
"Numerous references for these rules respecting the sources of modern Shi' $i$ doctrine exist, but perhaps the best one to refer to is a work of one of the most popular mujtahids of the common era, Muhammad Baqir al-Sadr. See Muhammad Baqir Al-Sadr, Al-fatāw'à al-wädiha (Dar Al-kitab Al-lubnani, Beirut 1983) 4. See also Chibli Mallat, The Renewal of Islamic Law (Cambridge University Press, Cambridge 1993) 35.
} 
The first of my groupings, the Islamist mujtahids, are best personified in the persons of Muhammad Baqir al-Sadr, an Iraqi jurist killed by Saddam in 1980, and Ruhollah Khomeini, his Iranian counterpart who studied in Najaf with Sadr, but ultimately returned to Iran to lead the Islamic Revolution. Sadr, more than Khomeini, developed the essential theory of juristic rule upon which Khomeini relied in his work, Wiläyat al-Faqīh, roughly translated as Guardianship of the Jurist. ${ }^{11}$ The theory is that the ideal form of government, and the one desired by God, involves a state that is ruled by Twelver Shi'i mujtahids through their interpretations of Shari'a, and that this state has come to exist in the form of the Islamic Republic of Iran. This is not to say that disciples of the theory find it impossible to live in non-Muslim liberal societies. Some of the mujtahid successors of Sadr and Khomeini, including Iran's current Supreme Leader, Grand Ayatollah Ali Khamane'i, do not deny this possibility, explicitly require their followers to obey the law in these cases and even permit working for the governments of such "oppressive states" in certain circumstances. ${ }^{12}$

However, ultimately, if God's Will is juristic rule, then the liberal society is a necessary if distasteful compromise and, almost by necessity, not an entity to which very much loyalty could sensibly be owed. The goal would be to Islamize the society and bring it under juristic rule if one can, or, if one cannot, as in the case of a nonMuslim state in the West, to bear patiently the patent injustice and oppression. The adherents of such a theory who can be found in the United States can be easily identified by their references to Iran as "the Republic", in much the same manner as New Yorkers refer to Manhattan as "the City". The implication is clear enough; there is but one Republic, and one City, in the world that really, finally counts.

Semi-Quietists are represented most prominently by the highly influential Muhsin al-Hakim, who died in 1970, and Ali Sistani, perhaps the grandest of the Grand Ayatollahs alive. Unlike the Islamists on the one hand, or the full Quietists on the other, the Semi-Quietists neither seek as their ideal model of statehood an Islamic state based on juristic rule, nor do they absent themselves from any sort of interjection into politics. Rather, as I will show, their entry into politics is limited, sporadic, often indirect and designed to protect Shi' $\mathrm{i}$ interests under threat. This makes it difficult to know precisely what their position would be in the context of a non-Muslim liberal society where core Shi' $i$ interests are not only unthreatened but also legally protected.

In fact, trying to figure out what Sistani and Hakim were up to (or, in Sistani's case, are currently up to) in their own societies almost resembles the reading of tea leaves rather than true analysis. Part of this is because their activity is limited and indirect, so it allows their disciples to draw whatever conclusions they might wish from their mentors' actions. This seems precisely the case with Muhsin al-Hakim, where eminent scholarship indicates incongruously that he reacted frostily to Khomeini's entry into Najaf and to the latter's political agitation (to Khomeini's intense disappointment), ${ }^{13}$ that he first was cool to Khomeini's ideas and later

\footnotetext{
"Mallat (n 10) 59-78.

${ }^{12}$ Website of the Office of the Supreme Leader Sayyid Ali Khamenei, 'Practical Laws of Islam', 'Working for Oppressive States' Available from <http://www.leader.ir/langs/EN/ index.php\#>

${ }^{13}$ Devin J. Stewart, 'The Portrayal of an Academic Rivalry: Najaf and Qum in the Writings and Speeches of Khomeini 1964-78' in Linda Walbridge (ed), The Most Learned of the Shi'a: The Institution of the Marja' Taqlid (Oxford University Press, New York 2001) 223.
} 
embraced him, ${ }^{1+}$ that he supported and indeed sponsored Da'wa, an Islamist political party, ${ }^{15}$ and that he forced Sadr to resign from Da'wa. ${ }^{16}$ Some of al-Hakim's ambiguities may have been strategic, thereby balancing the competing forces of Quietism and Islamism within the ranks of Najaf at the time, and ensuring that he influenced the government without overtly threatening it. He certainly tolerated some level of political activity by his children and some Shi'i scholars, among them Sadr and Bahr ul-Uloom. ${ }^{17}$ At the same time, there is no record of his direct participation in many of their activities, which would undoubtedly placate the Quietists.

But in addition, much of al-Hakim's professed activism may, I submit, also have been rewritten history, provided to learned and respected scholars like Chibli Mallat, Joyce Wiley, Linda and John Walbridge and Moojan Momen by alHakim's children and activist disciples, many of whom later took refuge in Iran and formed a party whose name until 2007, the Supreme Council for the Islamic Revolution in Iraq, betrays its obvious commitments in the political arena. Certainly if al-Hakim did not force Sadr to leave Da'wa, it is hard to see why he would have left, and thus the idea that al-Hakim founded a party and then forced its leading figure to leave it seems highly suspect. Moreover, there is nothing in alHakim's writings that I have found that would indicate the slightest affinity with anything Khomeini sought to create. The fact that, after his death, it was the Quietist al-Khoei and not Khomeini or Sadr who was generally viewed as the grandest of the mujtahids ${ }^{18}$ only seems to fortify this conclusion. At the same time, it is clear that al-Hakim did ban Shi' $i$ participation in the Communist Party and indeed even opposed Nasserite Socialism, ${ }^{19}$ did lend his name in 1960 to a political party composed of Islamist Sunnis and Shi $\mathrm{a}^{20}$ (though his activity in the party is very much unknown), and did participate as a young man in the 1925 Shi' $i$ uprising against the British. ${ }^{21}$

Was al-Hakim then a closet Islamist, not precisely a Khomeini-ite in wanting political power himself, but at least a jurist who sought to ensure that the state observed particular, proper Islamic bounds set solely by Shi' $i$ jurists, and therefore distrustful of any state that did not do so? Or was he less enamored of juristic political involvement, tolerating it in others but himself only interjecting when a particular, generally illiberal, movement or theory (Marxism, for example) threatened core, Shi' $i$ interests, in which case his attitude towards co-existence and broad social cooperation with other sects and religions would not necessarily be a negative one, if Shi'i interests were themselves legally protected? His seeming unwillingness to provide much by way of guidance concerning his views on Islam and the state is in many ways a

\footnotetext{
$\overline{{ }^{14} \text { Moojan Momen, An Introduction to Shi'i Islam (Yale University Press, New Haven, CT }}$ 1985) 262.

${ }^{15}$ Joyce N. Wiley, The Islamic Movement of Iraqi Shi'as (Lynne Rienner Publishers, Boulder, CO 1992) $32,42$.

${ }^{16}$ T.M. Aziz, 'The Role of Muhammad Baqir al-Sadr in Shi'i Political Activism from 1958 to 1980' (1993) 25 Intl J Mid E Stud 207, 210.

${ }^{17}$ Mallat (n 10) 16 (concerning Bahr ul-Uloom); Wiley (n 15) 32.

${ }^{18}$ Stewart (n 13) 223.

${ }^{19}$ Wiley (n 15) 36,40 .

${ }^{20}$ Ibid. 33-34.

${ }^{21}$ Ibid. 15
} 
microcosm for the confusion of much of Shi'i Islam over the subject, which is why I have spent so much time on him.

The ambiguity carries over to the person of Sistani, the most popular of the Grand Ayatollahs alive. Because he is alive and able to correct his own record, fewer liberties may be taken by disciples and others in interpreting his actions. My research assistant and I have scoured much of his work for ideas on political rule, including his entire risāla 'amaliyy'a, but he seems to endeavor mightily to avoid providing anything to analyze on this question, preferring instead to focus on the narrow, and in many ways arcane, Shi ${ }^{\circ} \mathrm{i}$ rulings concerning ritual, family matters and commercial transactions in which the believers might engage, none of which forces a direct conflict with state law by way of requiring from the believer that which is explicitly prohibited by the state, or vice versa.

Nevertheless, his limited and rather Delphic pronouncements in Iraq over the past few years concerning political issues provide fertile ground for speculation, as do his unrecorded meetings with various figures, many of whom subsequently provide a self-serving account that is neither accepted nor challenged by Sistani himself. We know, for example, that Sistani demanded early Iraqi elections, ${ }^{22}$ that he declared voting in the elections to be a religious duty and that he did not openly object to his name being widely and broadly associated with a Shi' $i$ alliance, though Iraq's former prime minister Ayad Allawi repeatedly and loudly maintained, also without objection from Sistani himself, that Sistani was not associated with the Islamist list and that his fatwa said no more nor less than that every Iraqi should vote. ${ }^{23}$ It should also be noted that the Shi' $i$ alliance itself did, at the time of the election, campaign on at least a platform of liberalism. ${ }^{24}$ While it is true that the participation of Islamist groups leads to some understandable skepticism regarding the veracity of the claim of an affinity for liberalism, the fact that this was an election slogan should not be understated. Presumably, if Sistani did have any control over the Shi' $i$ party (and he does appear to have had some, given its widespread use of his name and likeness) and was implacably opposed to liberalism, those posters would never have appeared.

Thus, a plausible case, even a persuasive one, can be made that Sistani at the very least tolerates the types of shared conceptions of justice and broad social cooperation in the political realm that are characteristic of liberalism. Nothing that he has undertaken is necessarily a refutation of any basic principles of liberalism. At the same time, alternative arguments can be made. It is clear that the party Sistani supposedly supported was comprised largely of Islamists and did insist on language in

\footnotetext{
${ }^{22}$ Larry Diamond, Squandered Victor?: The American Occupation and the Bungled Effort to Bring Democracy to Iraq (Times Books, New York 2005) 157-58. Diamond makes out Sistani to be some type of Shi 'i supremacist in his insistence on direct Iraq elections rather than the US favored "caucus" system that would ensure more American control over Iraq's interim legislative bodies. Needless to say, other, less charitable interpretations of the US refusal to permit a direct election based on the principle of one person one vote are certainly possible, as are more charitable interpretations of Sistani's demand for democratic rule.

?C Cf. BBC International Monitoring Service, 'Iraq Minister Criticizes Alleged Edict Urging Vote for Shi'i List', 15 January 2005.

${ }^{24}$ I was living in Iraq at the time and by far the most common poster of the Shi ${ }^{\circ} \mathrm{i}$ bloc, the United Iraqi Alliance, in the area where I lived and worked was one that read "The United Iraqi Alliance is the hope of liberals" (emphasis supplied, translation by author). See also Financial Times Global News Wire, 'Shi 'ites Begin Preparations to Urge People to Vote' (15 January 2005) (reporting the use of the same campaign poster).
} 
the Constitution prohibiting the legislature from passing any laws that violate the "firm rulings of Islam". ${ }^{25}$ This is broadly illiberal on two fronts. It potentially denies certain rights of freedom and equality (in particular, gender equality) associated with liberalism, though whether or not this is the case is questionable, given that the same Article prohibits the legislature from passing laws that violate rights set forth in the Constitution, among which gender equality is unambiguously included. ${ }^{26}$ In addition, the provision seems to limit the possibility of shared conceptions of justice beyond those that might be considered Islamic, thereby excluding Iraq's Christian and other religious minorities and the substantial population of secular Iraqis uninterested in having religion play any role in the public sphere. To interpret Sistani's call for democratic and liberal rule as being strategic and limited to those areas in which Shi' $i$ control is likely is therefore, admittedly, plausible.

Sistani provides no further guidance beyond these vague incursions into state policy in Iraq on the relationship Shi' is should have to a non-Muslim liberal state. He does provide ethical guidance to the believer, and ideas on ritual observance, but says precious little about broader social and political participation. This reticence extends even to the English or French versions of his website, which presumably are written primarily for Muslims in non-Muslim liberal states.

Thus, the semi-Quietists, who probably at this time lead the bulk of the Shi'i devout, seem to have developed deliberately ambiguous positions on the issue of the relationship of Islam to the state, and the question of whether or not a liberal state can legitimately exist and function on the basis of shared conceptions of justice and broad social cooperation that transcend the Shi'i Muslim paradigm. How this issue is ultimately resolved is of fundamental importance for the future of Shi' $i$ Islam, given the relative influence of the Semi-Quietists in contemporary affairs.

The third group of jurists is comprised of the Quietists, represented most prominently by the Grand Ayatollah Abul Qasim al-Khoei, who led Najaf following alHakim's death and among whose pupils were Ali Sistani, Muhammad Fadlallah and even Muhammad Baqir al-Sadr. Al-Khoei's distaste for juristic political activism is quite clear from his writings and the entire lack of any sort of political discussion within them. When asked about the doctrine of the Guardianship of the Jurist, alKhoei replied, one must assume with thinly disguised scorn given what the term meant to Khomeini, about the juristic responsibility of taking "guardianship" of orphans otherwise uncared for. ${ }^{27}$ Moreover, all of his pronouncements seem deliberately designed to avoid any sort of interference with the state. He scrupulously avoids in his extensive digressions on lengthy and cumbersome rules for proper Islamic behavior, for example, any direct conflict with the state and indeed does not mention the state. Thus, for example, rules of commerce, to which believers may adhere voluntarily, are provided in detailed form, as are requirements of alms giving, rituals of worship, rules of marriage and divorce, and pure and impure substances. ${ }^{28}$ Omitted are clear areas of conflict, among them international relations and criminal law. As a result, some of these rules may permit what the state prohibits (as in the age of marriage) or prohibit what the state permits (as in the consumption of alcohol), but a

\footnotetext{
${ }^{25}$ Iraq Const. Art 2(1), Official Gazette of the Republic of Iran (28 December 2005) 4012.

${ }^{26}$ Ibid. Art. 2(2); 14.

${ }^{27} \mathrm{Abū} \mathrm{Q} a \bar{s} i m$ Ibn 'Alī Akbar al-Khoei, Sìrat al-najāh fī ajwibat al-istifă'āt (Dar al Mahajoh al-bayda, Beirut 1995) 10.

${ }^{28}$ See generally Abū Qāsim Ibn 'Alī Akbar al-Khoei, Minhaj al-șăliḥinn (Dar al-Fahra', Beirut 1981)
} 
reader is hard pressed, except perhaps at the very margins of some of the doctrine of commercial activity, and that by a commercial law professor like me looking desperately for a discrepancy, to identify anything required by the Shari'a and prohibited by the state, or vice versa. This is not unusual in the risäla 'amaliyya, which after all is meant as a guide to the faithful on how to conduct their own affairs in accordance with God's Will (as noted above, Sistani's writings as a Semi-Quietist reflect much the same in his own risăla amaliya), but al-Khoei's absolute silence in any other pronouncements or writings on all matters relating to the state is in fact quite remarkable. $^{29}$

It seems eminently possible to be a devoted follower of al-Khoei Quietism and a liberal. Al-Khoei's own son took exile in London, was close to Tony Blair, not to mention the United Kingdom's Chief Rabbi, Jonathan Sacks, ran al-Khoei's large charitable network throughout London, supported British intervention in Afghanistan, denied any clash of civilizations in doing so, and called for an Iraq built largely on the 1925 Constitution, which could be fairly described as generally liberal, and certainly as liberal a document as was practicable in the circumstances. ${ }^{30}$ This is not, let me emphasize, a marginal individual whose influence is limited to Western scholars and intellectuals; this is the son of the Grand Ayatollah of Najaf. I have met many deeply fervent Shi'i believers in the United States, and while some certainly view Islamic government as the ideal to which to aspire and anything else as incorrigibly corrupt and unjust, it is clear that others hold a very different view. Devout Shi'a in the West today work on police forces, vote, pay their taxes, and engage in political advocacy, very much in the mold of the younger al-Khoei. Their commitment to shared ideals of fairness, public justice and equality before the law with non-Muslim fellow citizens, ideals from which a liberal state can be built, hardly seem in doubt.

Of course, other interpretations of Grand Ayatollah al-Khoei's Quietism are possible. One line of argument runs that the severe repression by Saddam Hussein forced al-Khoei's silence, a highly dubious proposition given that al-Khoei was a Quietist

\footnotetext{
${ }^{29}$ I have only one small qualification to add to this otherwise complete account. Devotees of al-Khoei and supporters of the 1991 Shi ' $i$ uprising against Saddam following the first Gulf War insist that al-Khoei was an active participant in the uprising. Moreover, they insist that throughout the Iraq-Iran war, he prohibited Iraqi Shi ' $i$ participation in the conflict and, moreover, point as evidence of his disenchantment with Baath rule to a 1981 fatwa wherein alKhoei asked followers not to give money to him directly for charitable purposes, but rather to distribute it in the areas in which they lived. As to the fatwa a variety of explanations could be offered, not all of which are necessarily political or related to Baath rule. There is no doubt that expenditures to the al-Khoei seminaries outside of Iraq has resulted in the building of massive social service programs, not to mention libraries, schools and mosques, throughout the world, from India to London to New York (Walbridge [n 13] 239). There are many reasons, all laudable, that a jurist would choose to engage in such projects outside of the limited confines of Najaf that have nothing to do with Saddam Hussein's rule. As for his support of the Intifada or prohibition of Iraq army participation, there is no evidence to support either claim, a fact that al-Khoei devotees attribute to the impossibility of such information being disseminated during Saddam's era. Suffice it to say, without by any means denying the possibility of either of these contentions being true, I have chosen not to address them given the atmosphere of uncertainty surrounding them. In any event, it would be fair to say that if true, they would be a dramatic departure from al-Khoei's otherwise persistent silence on such matters.

${ }^{30} \mathrm{~A}$ number of references relating to the younger al-Khoei' life are available. For a short, easy summary in English, see 'Obituary, Abdul Majid al-Khoei' Guardian Unlimited (London, 12 April 2003).
} 
long before Saddam's repression had taken full hold over Najaf, when the more Islamist scholars were quite active. Another common theory is that al-Khoei does not so much accept the potential legitimacy of liberal government, but rather believes that political activity is inherently sullying, and that the state, any state, is an epiphenomenon from which a true believer should be alienated, at least until the Hidden Imam, Shi' $i$ Islam's version of the Messiah, returns. But in that case one might expect prohibitions of various sorts against the believers working in government ministries, against their serving in the police force, or against their joining political parties. There is very little evidence that any of this was forthcoming from al-Khoei, not even when Sadr was organizing the Islamic revival.

However, it is important to note that while one may legitimately adhere to a form of Quietism and accept a theory of liberalism, such a commitment is not required. That is, nothing that the Grand Ayatollah himself said suggests voting is better than not voting, or supporting the police is better or worse than ignoring them, other than to the bare minimum extent necessary to comply with the law. Liberalism is not foreclosed, but neither is nearly entire alienation from the state.

The final category, of Ambiguous Liberalism, is in fact entirely my own making, and I put only one jurist of significance into it, Muhammad Hussein Fadlallah of Lebanon. That Fadlallah has dwelled more on a political theory that at least starts to smack of liberalism than other jurists should strike the reader as both shocking and yet in some ways entirely expected. As to the former, though he denies it, Fadlallah is alleged to be the spiritual leader of the militant Hezbollah, whose loyalty and material ties to deeply illiberal Iran run deep. For this, he has been branded a terrorist by the United States. ${ }^{31}$ Indeed, his stridency towards the United States and his militancy towards Israel are quite clear throughout his extensive work. ${ }^{32}$

Yet at the same time, as a Lebanese jurist, Fadlallah is better situated than most to develop liberal ideals. He neither lives, as Khomeini and Sadr did, in times and places where Islamic Revolution is possible, nor did he develop his thought, as al-Khoei, alHakim and Sistani did, in places where political involvement was often lethal. At about half the population, the Shi'a of Lebanon are neither numerous enough to dominate politics, as they are in Iraq and Iran, nor few enough to make involvement of limited use. Disengagement seems foolish and self-destructive, and attempts to force the state into an Iranian mold even more so. The result is actually quite fascinating: a deep antipathy to the United States combined with as close an embrace of American liberal thought as any Shi'i jurist has come.

On his website, ${ }^{33}$ for example, Fadlallah makes entirely clear that, to use the Rawlsian phrase, Islam's "comprehensive theory of the good" does not conflict with the necessary commitments of political citizenship in a liberal state. Fadlallah

\footnotetext{
${ }^{31}$ US Dept. of Treasury, 'Terrorism: What You Need to Know about US Sanctions', 8. Available from $<$ http://ftp.fas.org/irp/threat/t1 l ter.pdf $>$ (accessed 1 December 2008).

${ }^{32} \mathrm{Cf}$. Fatwa of Muhammad Hussein Fadlallah concerning a Boycott of American and Israeli Goods. Available in English from <http://english.bayynat.org.lb/Issues/boycott.htm> (accessed 1 December 2008), (describing the US and Israel as being in a "war with Muslims and Islam that is being waged under the pretense of fighting terrorism").

${ }^{33}$ Fadlallah, like all the Grand Ayatollahs, tends to engage his followers any number of ways, including proclamations through deputies, Friday sermons that are often then distributed on audiotape or placed on the internet, books, and a reasonably sophisticated website. Though familiar with many of Fadlallah's works, I focus primarily on his website, and specifically the English version of it, which would be a fairly important source of information for his followers living outside Lebanon.
} 
explicitly indicates that there is a "general Islamic principle" of coexistence with other faiths through "a social contract based on the concept of citizenship" ${ }^{3+}$ He indicates that reaching common and overlapping ground as a means of securing coexistence with non-Muslims with whom there are disagreements is part of a Muslim's "cultural and human responsibility". 35

Fadlallah almost suggests that this type of pluralism is preferable. Certainly he indicates that knowing people from other faiths and ethnic groups permits a Muslim to advance his own knowledge, as required by Islam, and he also speaks broadly and approvingly of pluralism as "a marvelous humanistic picture of unity in diversity or diversity in unity in which the legislation provides human rights for the minorities that do not isolate them from the other citizens in the majority and do not hinder them from preserving their religious or particular identities in what does not violate the general law". ${ }^{36}$ Unlike al-Khoei, isolationism is firmly rejected by Fadlallah in favor of "legislation" that ensures equality between citizens. This "legislation" is referred to as a "general law", and Fadlallah makes clear that it forms the basis for the citizen's commitment to the state.

Fadlallah's more technical and arcane rulings on ritual fortify these sorts of notions as well. Unusually among Shi' $i$ jurists, he has declared that all people should be presumed to be ritually clean (tāhir), where other jurists usually declare all nonMuslims to be impure (najis). ${ }^{37}$ The idea that other humans are not impure and therefore to be avoided has, of course, immense consequences for the extent of interaction that can take place with non-Muslims without compromising the ability of the Muslim to remain pure for daily ritual activity. It also removes a fairly significant psychological barrier to broader societal engagement.

While I would not claim that my analysis of Fadlallah's extensive writings has been rigorous, I think it is sufficiently complete to demonstrate that he has considerable affinity with liberal notions. Cynics may argue that much of this is disguised doublespeak and hypocrisy, that in fact Fadlallah would secretly prefer a strong Islamic state, that Hezbollah shares this conviction and that nothing other than expediency compels Fadlallah to advance these views, especially in English, in order to make his ideas accessible to Westerners. Even if true, this would prove little. The point is that as a Shi ${ }^{\circ} i$ - an orthodox, conservative, believing Shi ${ }^{\circ} i$ following Shi ${ }^{\circ} i$ tenets - liberalism seems to be preferred in Fadlallah's writings. His words would never be taken by the community to be doublespeak or hypocrisy, so it matters little whether or not there is some underlying motivation to his views; they have been advanced and a Shi ${ }^{\circ} i$ is free to regard them as sincere.

If this is true, why have I labeled Fadlallah an "ambiguous liberal" as opposed to an unabashed liberal? Where is the nuance that must be heeded? It can be found in the

\footnotetext{
${ }^{3+}$ Muhammad Hussein Fadlallah, 'The Principles of Co-Existence' Available from <http:// english.bayynat.org.lb/Issues/coexistence.htm> (accessed 1 December 2008).

${ }^{35}$ Ibid.

${ }^{3 n}$ Ibid.

${ }^{37}$ Muhammad Hussein Fadlallah Figh al-sharī'a (Dar al-Malak, Beirut, 1998), 77. Fadallah suggests that non-Muslims, especially if not Christian or Jewish, may be regarded as ritually impure as a matter of caution, but that the stronger ruling is that they are not. Grand Ayatollah Sistani, by contrast, rules that non-Muslims who are not Christians or Jews are certainly impure, that the general rule concerning Christians and Jews among jurists is that they are impure, and that therefore sufficient doubt exists to make it better to avoid them. Ali Sistani Al-masā'il al-muntakhiba Qum Dar Al-Fahra', Beirut, 1998), 152.
} 
other side of his writings, those concerning political issues, the strident tone towards the West and the deep and abiding antipathy for Israel, which I choose to address through his references to emigration to the West.

For a liberal, Fadlallah seems to have a starkly negative view of emigration to Western nations. This is not in the sense that he deems it necessarily sinful, for he clearly is sympathetic to those he describes as his "brothers" in some cases and "sons" in others, who are living abroad, but in terms of the hardships he assumes they must be enduring. ${ }^{38}$ Gone is the language of a "humanistic picture" of diversity in unity, to be replaced almost by a metaphor of prison. Fadlallah speaks of the "harsh circumstances" imposed on the believers who are forced to travel abroad "to earn a decent living" (as if no other circumstances could explain a Muslim's presence in the West). ${ }^{39}$ He offers God's words as consolation and comfort in the dark hours they are forced to be abroad. He urges them to obey the law, not on the basis of its legitimacy, or the legitimacy of the state promoting it, but to set a higher example, to demonstrate Islam's moral light even in the darkest corners of the West. In this, he is a comrade in arms with Ayatollah Khamne'ei of Iran, whom he extols in his struggle against Western influence. ${ }^{40}$

What then are we to make of this? In Lebanon, broad social cooperation is possible, but in the West, the Muslim should retreat, acknowledge the difficult circumstances requiring him to be there, and obey all laws but avoid excessive intermingling with evil and unjust regimes that seek to destroy Islam and weaken the believers.

It is at this junction of political theory and state practice where liberalism finds its roughest terrain amongst Shi 'is. The reality is that very devout Shi' $i$ s, much like their Sunni counterparts, generally harbour a deep and abiding resentment of and contempt for the West. As a result, the word liberalism, given its Western foundations and its association with Western states, is problematic, and any association with the West therefore becomes difficult.

Added to this is a profound ignorance about what life in the West must be like among the mujtahid decisionmakers and many of their students. If I might return to my own personal story, while relating the outrageous assault on my father in Medina to a senior associate of Grand Ayatollah Sistani in Baghdad, the gentleman, thoughtful and intelligent throughout my dealings with him, asked me whether or not this was something perhaps I would be used to in my life in the Muslim-hostile United States. Indeed, he regarded with some incredulity my immediate response that throughout my entire life in that non-Muslim liberal society, not once did a single police officer or other agent of the state raise his hand against me or my father, and had he done so, we would immediately have sought legal recourse. Of course Grand Ayatollah Sistani, like the other Grand Ayatollahs, have advisers in the West better able to discuss life as a non-Muslim in the West, but the effect of this prevailing picture on their considerations of this issue cannot be gainsaid.

Fadlallah's own writings demonstrate this chasm of distrust. He sees the social contract as founded not by Hobbes, Rousseau or Locke but in the Constitution of Medina, written by Muhammad with Medina's Jewish tribes. ${ }^{41}$ Human rights come

\footnotetext{
${ }^{3 x}$ Muhammad Hussein Fadlallah, 'The Message to Emigrants' Available from <http:// english.bayynat.org.lb/Issues/emigrants.htm> (accessed 1 December 2008).

${ }^{39}$ Ibid.

${ }^{41}$ Ibid.

${ }^{41}$ Fadlallah (n 34).
} 
not from Kantian notions of human autonomy but from the Qur'an itself. Western ideas are thus clearly given an Islamic patina. Certainly the reaction I receive in mosques is markedly different if I use terms such as "general law" rather than "secular law" and "coexistence" rather than "liberalism", and quote extensively from Fadlallah and not Rawls.

In itself, this sort of ahistorical legend creation - of Islam founding Western political theory - is harmless and potentially salutary, in the same manner as the historically preposterous insistence of American Muslims that jiha $\bar{d}$ does not refer to war or physical violence except in the most extreme circumstances, and that its primary definition is a spiritual one. As noted above, harmony with historical doctrine is never what gives life to the law and the fact that these ideas conflict with traditional understandings is hardly the point.

But a deeper problem lurks, one that might well explain the marginality of figures such as the Muslim feminists earlier referred to. If one begins to mimic excessively Western ideas and notions, clothing them in Muslim rhetoric to justify the approach, eventually those Muslims who care deeply about Muslim doctrine catch on to the game, and dismiss the effort as a wolf in sheep's clothing. This very real hindrance complicates enormously the efforts of those who seek to expand liberal notions throughout the devout, whether in non-Muslim societies in the West, or even in the Middle East; it is their association with the West that can be a problem, not the content of the liberal ideas.

In the same manner that Nixon could go to China, Fadlallah can credibly adopt Western political theory, at least in significant part. Moreover, the adoption of these ideas among large numbers of devout Shi' $a$ is a readily apparent fact. Nevertheless, a very real political problem, of antipathy towards the West developed from a range of anti-colonial, anti-imperialist and anti-Zionist sentiments (whether justified or not), hinders the ability of ideas such as Fadlallah's to spread even further, much more than does the substance of the Shi ' $\mathrm{i}$ positions. I remain hopeful for the future, given the attitudes of many of the Shi'i clergy towards the theory of liberalism, yet somewhat guarded in my optimism given the ongoing political divide. 